\section{THE VISIT OF THE BRITISH ASSOCIATION TO PLYMOUTH}

THERE are very good reasons for anticipating that the Plymouth meeting of the British Association will be at least up to the average in interest and success. Indeed, in some respects it is anticipated that it will be unusually attractive; and the attendance is likely to be much larger than from the distance west was at first thought probable. And as the details of the local arrangements approach completion so do the outside attractions, rendered available for the pleasure or information of the visitars, increase and multiply. The Government authorities have kindly consented to render every facility in their power for the inspection of the great establishments which constitute Plymouth and Devonport one of the chief arsenals in the world. The dockyard and Keyham yards will be freely open; those who desire to inspect the famous biscuit machinery at the Royal William Victualling Yard will be enabled to do so ; there will be gunnery practice and probably torpedo practice also to be witnessed on board the Cambridge. The Breakwater of course can be seen at any time from Plymouth Hoe, and visited whenever weather will permit, which unless a gale is blowing it always does. The Breakwater Fort, reared on an artificial island of stone in the Sound immediately within the Breakwater, granite-capped and iron-plated, is by far the most interesting of the great chain of forts wherewith the Three Towns are girdled, and this too, it is hoped, will be open to inspection. The Eddystone will be visited on the Saturday, as already stated; but it must be understood that it is by no means certain that a landing can be effected. In fair weather, even, there is at times such a swell there as to render landing difficult, and even dangerous, while in rough weather it is impossible.

The excursion arrangements have been somewhat extended since our previous notice. On the Saturday, in addition to the excursions to the Eddystone, Lee Moor, and Iskeard for the Caradon Mines, it is now proposed by the citizens of Exeter to invite a large party of the members to this famous city, which abounds in objects of antiquarian interest, and which is noted for the hospitality with which it receives its guests. Iskeard too, is moving in the same direction; and the proprietors of Lee Moor Clay Works, Messrs. Martin, intend to make provision also for their visitors. After the clay works have been seen and justice done to the luncheon, there will be ample opportunity for a delightful ramble on Dartmoor. Shell Top and Pen Beacon, with their magnificent views and prehistoric remains, are within very easy distance, and good walkers will have the opportunity of enjoying some of the most romantic scenery in Devon, in the valleys of the Plym, and other moorland rivers.

The excursion arrangements for the Thursday remain unchanged; but there has been a considerable addition to the list of available attractions. The engineers of the party, through the kindness of Mr. Margary, engineer of the Great Western Railway for the district, will be enabled to inspect the Royal Albert Bridge to their heart's content-even to a scramble through the tubes. The great granite works and granite quarries of Messrs. Freeman at Penryn; the mines of Dolwath, Tincroft, and Carn Brea (by the kindness of Capt. Josiah Thomas and Capt. Teague); the pneumatic stamps of Mr. Husband, at the Hayle Foundry; the tin smelting works of Messrs. Bolitho, at Penzance, will ail, by the courtesy of their proprietors, be available to be visited by members of the Association. And as the Earl of Mount-Edgcumbe has kindly opened his magnificent park and his romantic mansion of Cotehele, so Sir John St. Aubyn permits his famous and historic residence, St. Michael's Mount, to be visited by those members of the Association who may find their way so far west.

The public museums of the two counties will, we believe, be all open to the members. The chief are that at Exeter, that of the Royal Cornwall Institution at Truro, and that of the Royal Cornwall Geological Society at Penzance. Mr. C. C. Ross, of the latter town, has one of the best private collections of minerals in the West of England, and will gladly show it to all who feel interested in mineralogy. Then there are the museums of the Torquay Natural History Society, the specialty of which is its Kent's Cavern collection, which will form one of the attractions of the Torquay excursion, and the Museum of the Plymouth Institution, in which will be found a magnificent collection of flint implements and weapons lent and arranged for the occasion by Mr. Brent.

There will be several local papers contributed to the various sections, but the list is hardly likely to be so long as at the meeting of $18.4 \mathrm{I}$, when the local contributions were unusually numerous.

The Pharmaceutical Socisty will, as usual, hold their meeting immediately prior to the meeting of the Britis $h$ Association at Plymouth, and the Mineralogical Society and the Society of Public Analysts, will also meet at Plymouth during the Association week.

\section{THE GORILLA}

GINCE Monday last the young gorilla from the Berlin Aquarium has been exhibited, during most hours of the day, at the Westminster Aquarium, in company with a chimpanzee. This is the first occasion on which a living gorilla has been publicly exhibited in this country as such, an earlier specimen some years ago, in a travelling menagerie, having passed for a chimpanzee during its life-time.

The gorilla, which is about three years old, appears in excellent health, and differs most strikingly from its companion in the blackness of its face and extremities, the smallness of its ears, the shortness of its muzzle, the great development and breadth of the alae of its nose, the shortness and softness of its thick-set body-hair, the presence of a frontal hair-tuft, the breadth and flatness of its back, which is also capable of greater backward bending, the smallness of the four outer toes, which are free for but a short distance, the breadth of its hands, and the massiveness of the nape of the neck. The conjunctiva is black, and the eye intelligent. We think that no one interested in natural history should lose the opportunity of seeing this particularly interesting Anthropoid ape,

\section{BRISINGA}

NEARLY a quarter of a century ago the celebrated Norwegian poet and naturalist, $P$. Chr. Asbjörnsen, was dredging in the interior of the picturesque Hardangerfjord, when, at a depth of about 200 fathoms, the dredge brought up a wonderful new star-like Echinoderm, quite unlike any form that had been up to that moment described. From a little circular disc of about an inch in diameter there issued eleven spreading arms or rays upwards of a foot each in length. These were armed along the edges with several rows of long spines; these arms, while standing near together at their base, generally taper away gradually to their tips. The colour, though variable, was, on the upper or dorsal surface, of a more or less red hue and paler, often to whiteness, on the under surface. On the lower surface of the disc, and occupying the central space, is seen the mouth-like aperture of the alimentary system, and spreading away from it along the centre of each ray-like arm, are the deep ambulacral furrows, so called because from these furrows issue the ambulacra or water-feet. These form two uninterrupted rows, and are flanked by several palisades of strongly-developed spines, the outer ones being the longest. All these spines are enveloped in an integument which is covered with strange-looking Pedicellariæ. 